\title{
Design of 'Anjul' Seed Metering Mechanism for Round Seeds and its Seed Pattern Characteristics
}

\author{
Vinod Kumar*, Vijaya Rani, Mukesh Jain, Anil Kumar, Sushil Kumar and Naresh \\ Department of Farm Machinery and Power Engineering, CCS Haryana Agricultural \\ University, Hisar-125004, Haryana, India \\ *Corresponding author
}

Ke y w o r d s
Seed metering,
Anjul, Okra,
Planter, Sand bed
test, X-ray test of
seeds

A B S T R A C T

Seed metering mechanism is the core functional component of any planter. A new seed metering mechanism was developed for round seeds with the cell design termed 'Anjul' aimed to eliminate seed damage and obtain better seed singulation of seeds while metering. The 3D model of the cell and its housing was prepared in design softwareSketch Up. It composed of two semi-circular split seed metering rollers mounted on a mild steel circular flange and a seed box with feeding chute. The seed metering roller was fabricated from acrylonitrile butadiene styrene polymer with the help of a 3D printer. It was tested in sand bed test for its seed distribution characteristics. The accuracy of seed placement was tested for okra seeds. The cell size of $7 \mathrm{~mm}$ which was a optimum match to the seed size of okra, at peripheral speed of seed roller of $1.4 \mathrm{kmh}^{-1}$ was selected for the test. It was found that the most of the time, single seed per hill were obtained with the metering mechanism. The maximum coefficient of variation of seed spacing observed was $15.69 \%$. Missing index and multiple indexes were both zero. There was no visible damage to the seed by the planter. A comparison of X-Ray photographs of metered seeds with normal seeds was done for assessing seed damage. No crack or breakage in the metered seed was.

\section{Introduction}

The seed metering mechanism plays a crucial role in success of any planter. It influences design and performance parameters of the planter. In manual dibbling of seed, the nonuniform and high plant population adversely affects output of different crops (Singh et al., 2007). Uniform distribution of seed in vertical i.e. depth as well as horizontal dimensions i.e. seed to seed and row to row distance results into increases in crop yield, frequency and reliability of cropping, and crop returns
(Murray et al., 2006). Today's intensive cropping also demands timeliness of operations by appropriate use of agricultural machines.

In recent past, different mechanical seed metering devices have been introduced. Sahoo and Srivastava (2000) used semi-circular shaped cups for metering of seeds in the seed drill. The seed retention and release of the cups was not good due to vibration and shocks involved. By changing the cups (Garg and Dixit, 2003), this metering mechanism can be 
utilized for different crops. Mishra et al., (2015) modified these cups to a shape which was cylindrical at top and conical at the bottom for better retention of seeds of crops like groundnut, paddy and green gram. The arc-shaped grooves over the periphery of cylinder were developed for metering of bothsmall and large seeds (Gaixia et al., 2015). For small seeds, the groove was shallow and the number of grooves was more, while metering big seeds, the depth of the groove was decreased up to not less than half the thickness of the seed in order to reduce the damage to seed. Seed metering by inclined plate with triangular and semi-circular cells (Yadachi et al., 2013) showed higher multiples of carrot seeds. But the seed metering mechanism which meters the single seed are relatively better in performance (Reddy et al., 2012).

The objective of this study was to develop a seed metering mechanism for round seeds like okra, spinach, etc. aimed at eliminating the shortcomings of previous metering mechanism, namely, seed damage, seed singulation, cost and ease to manufacture.

\section{Materials and Methods}

\section{Design of 'Anjul' seed metering mechanism}

The seed metering mechanism influences the design and performance of the planter. The basic considerations in designing of seed metering mechanism were minimal damage to the seed, good seed singulation while metering and low cost of manufacturing. It should be easily repairable and readily available. Taking these considerations into mind, a 3D model of seed metering roller with the cells on its periphery was prepared in design softwareGoogle Sketch Up. The cell design was aimed to house the seed completely while maintaining good cell fill percentage. As a replaceable metering roller is crucial to meet the farm requirements and timeliness of operation (Reddy et al., 2012), the seed metering roller was designed in split form (two semi-circular parts, Fig. 1). It can be replaced in the field by un-screwing the screws which attach it to a circular metal plate.

The shape of the cell was scalene ellipsoid having cut by a cylindrical surface of radius 6 $\mathrm{cm}$ resulting into a ellipse mouth with two axes viz. major and minor (Fig. 2). The cell was a hemisphere at bottom to hold the seed and a trowel at top to guide seed to the hemispherical part.

\section{Dimension of seed metering roller}

The internal diameter and thickness of seed roller were $40 \mathrm{~mm}$ and $15 \mathrm{~mm}$, respectively (Fig. 3). Its external diameter was $60 \mathrm{~mm}$. The seed roller was made of acrylonitrile butadiene styrene- a thermoplastic polymer. Two holes, each having diameter $4 \mathrm{~mm}$, on each half seed roller were provided to mount it on a circular metal plate having diameter of $60 \mathrm{~mm}$. The circular mild steel plate was attached on one side of the shaft that receives power from power transmission unit through driven sprocket. The number of cells on each seed metering roller was kept eight which were located equidistant from each other.

The cell size is designated by minor axis of the elliptical mouth of the cell (Fig. 3) measured along axis of rotation of seed roller at its periphery as seed accommodated by the cell depends majorly on it.

Based on preliminary tests, okra seed was chosen for sand bed test because its shape which is round (sphericity-86.4\%, Kushwaha et al., 2007), is similar to shapes of seeds of some other vegetables like coriander (sphericity-82.2\% to $91.1 \%$, Balasubramanian et al., 2012), spinach (sphericity-80.7\% to $82.1 \%$, Kilickan et al., 2010), soybean 
(sphericity-77.4\% to $85.1 \%$, Kenghe et al., 2013) and pea (sphericity-83.6\% to $85.1 \%$, Yalcin et al., 2007. The seed metering system tested for okra seed can also be used for planting other vegetables crops by varying cell size and seed to seed spacing as per requirement for different crops. Larger cell size can be used for large sized seeds. For okra seed, considering the cell as an ellipsoid, the dimension were

Major axis, $a=9 \mathrm{~mm}$

Minor axis, $b=7 \mathrm{~mm}$

Depth (axis mutually perpendicular to $a$ and $b$ ) $=7 \mathrm{~mm}$

\section{Seed box design}

A seed box with feeding chute was designed (Fig. 4). A cleaning brush was attached to feeding chute at top of the seed roller to wipe any extra seed in cells.

A flow control plate was mounted on seed box to avoid the expected overflow of seed in feeding chute.

The seed box was made from mild steel plate having thickness $1.0 \mathrm{~mm}$. The feeding chute was attached to the bottom of the seed box to feed seed to the seed roller. The slop of bottom surface of the feeding chute was $35^{\circ}$ to the horizontal. The slope of the seed hopper was kept modestly higher than the average angle of repose of seeds to ensure free flow of seed (Jayan and Kumar, 2004). The seed capturing conical funnel along with a seed tube of length $30 \mathrm{~cm}$ was attached below seed metering roller.

\section{Fabrication of the 'Anjul' seed metering rollers}

The seed metering rollers were fabricated with the help of a 3D printer (Fig. 5).

\section{Performance evaluation}

The okra seed was cleaned from foreign material, damaged seeds and impurities by manual picking and then passing through a metal screen having square pores of size $10 \mathrm{~mm}$. It was taken in the seed box. The seed metering mechanism was provided power from the ground wheel. The seed distribution characteristics were determined from the sand bed method.

\section{Seed distribution characteristics}

The uniformity of seed placement within the row was determined by using sand bed test. The seed metring mechanism was moved over the sand bed with the help of the planter. Based on preliminary tests conducted on the singularity of okra seeds for different sizes of cells at different peripheral speeds, the cell size of $7 \mathrm{~mm}$ at peripheral speed of metering roller of $1.40 \mathrm{~km} \mathrm{~h}^{-1}$ was found most appropriate among three cell size- $7 \mathrm{~mm}, 8$ $\mathrm{mm}$ and $9 \mathrm{~mm}$.

The uniformity of seed distribution pattern (hill to hill distance in row and seed to seed distance in a hill) of seeds sown by the planter were measured and following performance parameters were determined.

\section{Missing index}

The missing index is the percentage of spacing greater than 1.5 times the theoretical spacing.

$I_{\text {miss }}=\frac{n_{1}}{N} \times 100$

Where,

$\mathrm{I}_{\text {miss }}=$ Missing index, $\%$

$\mathrm{n}_{1}=$ Number of spacing $\geq 1.5$ theoretical spacing 
$\mathrm{N}=$ Total number of measured spacing

Missing index is thus an indicator of how often the seed skip the desired spacing.

\section{Multiple index}

The multiple index is the percentage of spacing that are less than or equal to half of theoretical spacing.

$\mathrm{I}_{\text {multi }}=\frac{\mathrm{n}_{2}}{\mathrm{~N}} \times 100$

Where,

$\mathrm{I}_{\text {multi }}=$ Multiple index, $\%$

$\mathrm{n}_{2}=$ Number of spacing $\leq 0.5$ theoretical spacing

$\mathrm{N}=$ Total number of measured spacing

Thus, it is indicator of more than one seed within the desired spacing.

\section{Quality of feed index}

The quality of feed index $\left(\mathrm{I}_{\mathrm{q}}\right)$ is the percentage of spacing that are more than half but not more than 1.5 times the theoretical spacing. The quality of feed index is an alternate way of presenting the performance of the misses and the multiples.

$\mathrm{I}_{\mathrm{q}}(\%)=100-\left(\mathrm{I}_{\text {miss }}+\mathrm{I}_{\text {multit }}\right)$

Where,

$\mathrm{I}_{\text {miss }}=$ Missing Index

$I_{\text {multi }}=$ Multiple Index

\section{Degree of variation}

Degree of variation (c) is a measure of the variability in spacing after accounting for variability due to both multiples and skips.
The degree of variation is the coefficient of variation of the spacing that is classified as single. Mathematically,

$\mathrm{c}=\frac{\mathrm{S}_{\mathrm{z}}}{\mathrm{X}_{\mathrm{ref}}}$

Where,

$\mathrm{S}_{2}=$ Sample standard deviation of the $\mathrm{n}_{2}$ observation

$\mathrm{X}_{\text {ref }}=$ Theoretical spacing

\section{Seed damage}

One of the important requirements of the seed metering device is that it should not cause mechanical damage to the seed. The damages caused to seed by metering devices are classified as:

Visible damage and

Invisible damage.

The visible damage (\%) is determined by counting the damaged seed as seen with normal vision in a sample of seed passing through the metering system.

The invisible damage is determined by X-Ray photograph of the seeds passing through the metering system. The metered seed sample is compared with normal seed sample for identifying any breakage to the seeds. The photograph is examined in $15 \mathrm{X}$ zoomed view in a image processing software. The seed damage (\%) is expressed as:

Seed damage $(\%)=$ Visible damage $(\%)+$ Invisible damage (\%)

Invisible damage $(\%)=$ (Percentage of damaged seed in X-Ray photograph of metered seed sample) - (Percentage of damaged seed in X-Ray photograph of normal seed sample) 


\section{Table.1 Seed distribution pattern of $7 \mathrm{~mm}$ cell at $1.4 \mathrm{kmh}^{-1}$ peripheral speed of seed roller}

\begin{tabular}{|c|}
\hline No. of hills \\
\hline 1 \\
\hline 2 \\
\hline 3 \\
\hline 4 \\
\hline 5 \\
\hline 6 \\
\hline 7 \\
\hline 8 \\
\hline 9 \\
\hline 10 \\
\hline Mean \\
\hline Coefficient of variation, $\%$ \\
\hline Multiple Index, \% \\
\hline Miss Index, \% \\
\hline Quality of feed index, \% \\
\hline
\end{tabular}

\section{Hill to hill distance $(\mathrm{cm})$ and seed to seed distance $(\mathrm{cm})$ in hill in parenthesis}

\begin{tabular}{|c|c|c|}
\hline R1 & R2 & R3 \\
\hline $16(1.5)$ & 19 & 14.5 \\
\hline 17.5 & 15 & 19 \\
\hline $17(1)$ & 17 & $13(0)$ \\
\hline 20 & 16.5 & 17 \\
\hline 21 & 14.5 & 16.5 \\
\hline 19 & 14 & $15(2.5)$ \\
\hline 13 & 16 & 19.5 \\
\hline 15 & 15 & 14 \\
\hline 19.5 & $14(3)$ & $16(2)$ \\
\hline $20(2)$ & 14 & 16.55 \\
\hline 17.8 & 15.5 & 15.69 \\
\hline 14.39 & 10.53 & 0.0 \\
\hline 0.0 & 0.0 & 0.0 \\
\hline 0.0 & 0.0 & 100 \\
\hline
\end{tabular}

Fig.1 Half seed roller
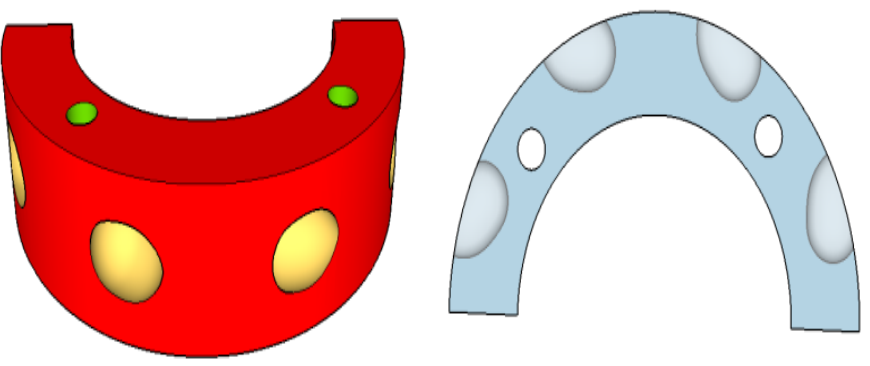

Fig.2 The Anjul cell (Left: side view, Right: top view)
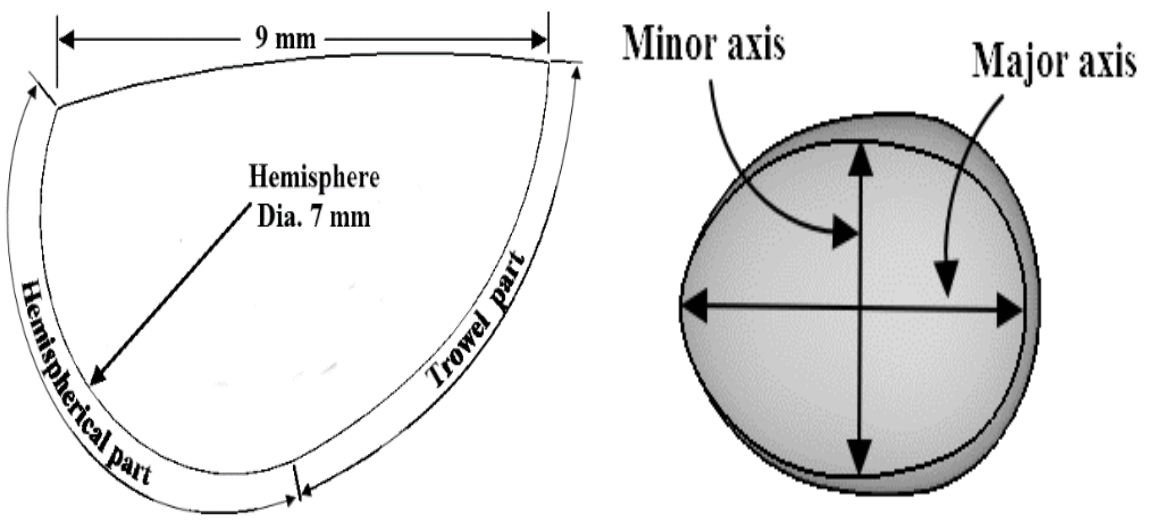
Fig.3 Seed roller dimension (Side and top view)
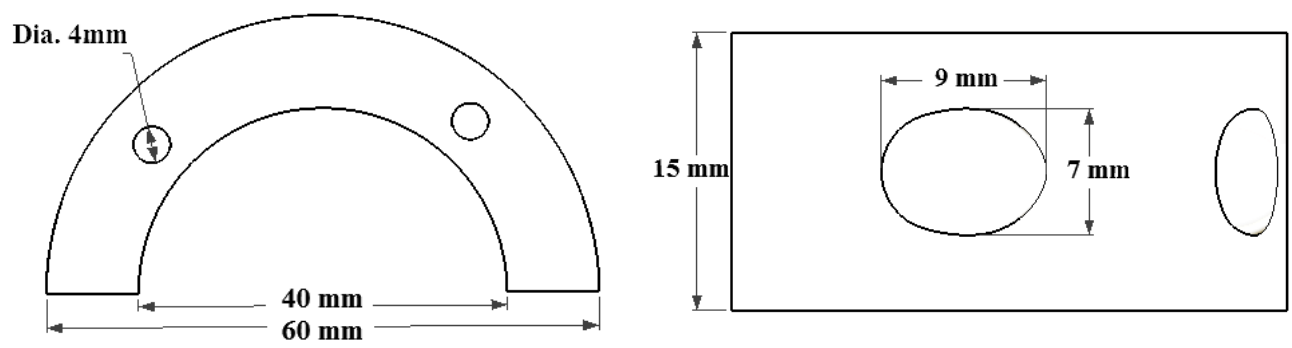

Fig.4 Seed box with seed metering roller and cleaning brush
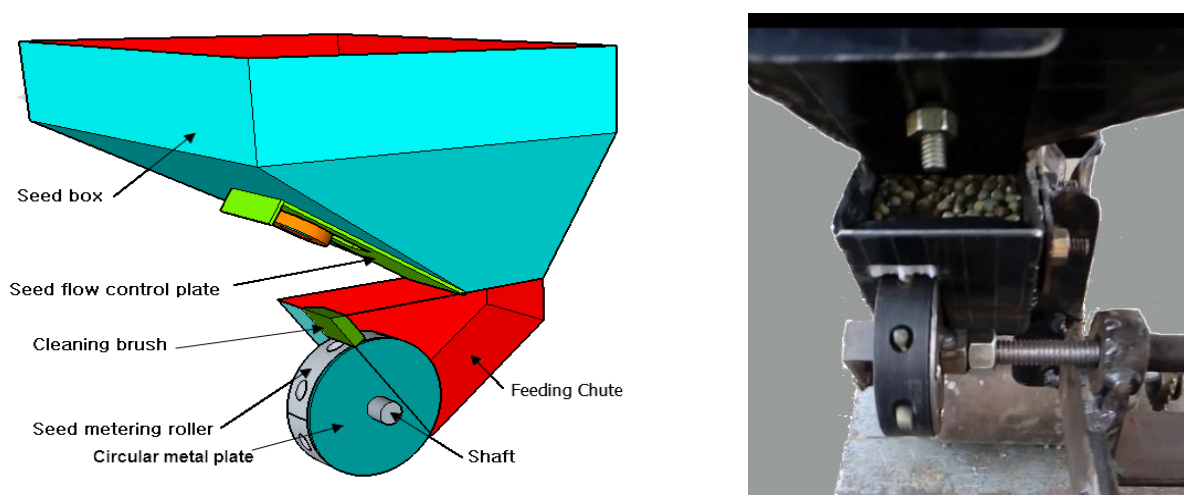

Fig.5 3D printed model of seed metering roller

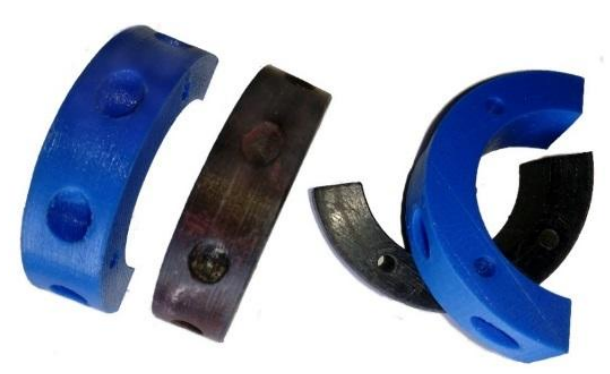

Fig.6 Magnified view of $\mathrm{X}$-ray photograph of metered seeds vs normal seeds

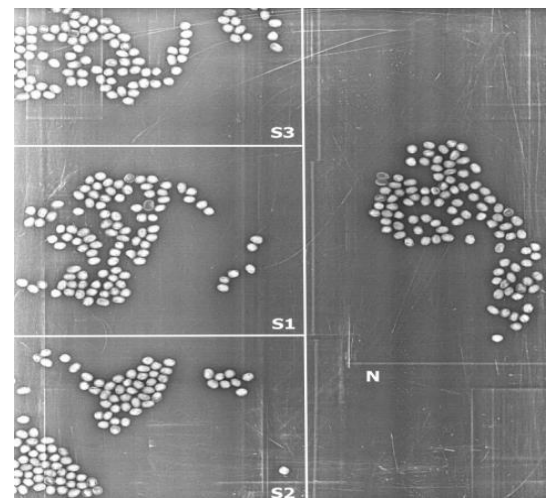

$\mathrm{X}$-Ray photograph of seed samples ( $\mathrm{N}=$ normal seeds; S1, S2, S3=Metered seed sample) 


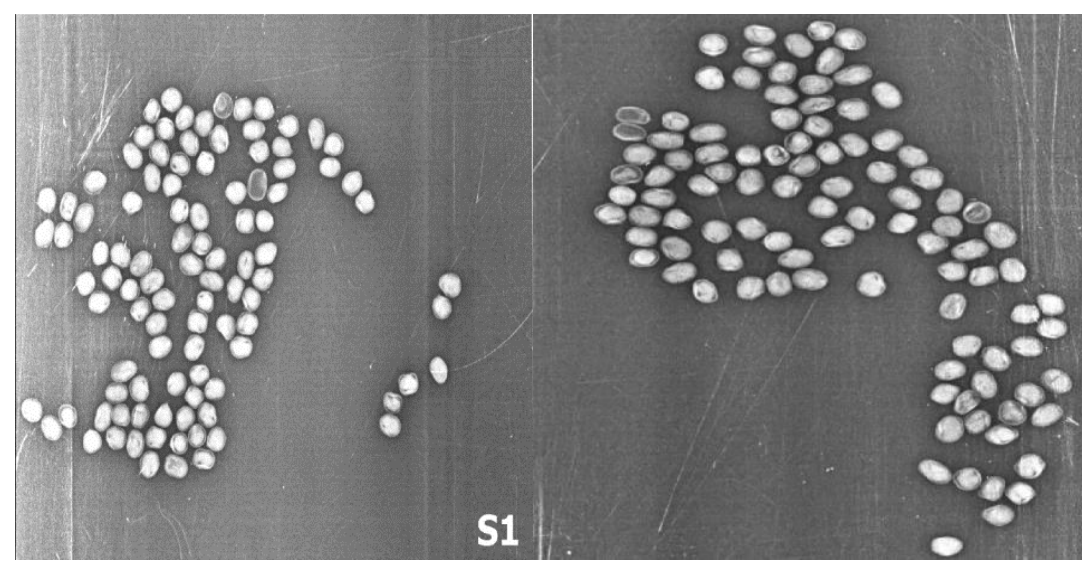

\section{Results and Discussion}

\section{Seed distribution pattern}

Seed distribution pattern which is represented by hill to hill distance and seed to seed spacing in a seed hill is given in Table 1 for 7 $\mathrm{mm}$ cell. The mean hill to hill distance was $16.61 \mathrm{~cm}$. Most of the time, single seed per hill were obtained with the metering mechanism. The seed to seed distance in a hill varied from 0 to $3 \mathrm{~cm}$. The coefficient of variation varied from $10.53 \%$ to $15.69 \%$.

Singh et al., (2005) reported coefficient of variation of seed spacing as $19.1 \%$ for cotton seeds using pneumatic seed metering mechanism.

Missing index and multiple indexes were both zero, i.e., no hill to hill distance was greater than $30 \mathrm{~cm}$ (1.5 times of recommended seed spacing in missing index) and less than $10 \mathrm{~cm}$ (0.5 times of recommended seed spacing in multiple index). Therefore, the seed metering by seed roller and their distribution within the row may be considered satisfactory.

\section{Seed damage}

The seed damage was analyzed with the help of X-Ray photographs of metered seeds. Normal seeds were also photographed for comparison. There was no visible damage to the metered seed. The photographs were studied in zoomed view for invisible damages. No seed damage observed in metered seeds (Fig. 6).

Bamgboye et al., (2006) concluded $3.51 \%$ seed damage in the manually operated two row okra planter with metering flutes made of Ayan (Distemonanthus benthamianus) wood. Dineshkumar et al., (2014) reported 1.236\% seed damage for pull type manual cotton planter having cell feed metering mechanism. Adekanye et al., (2006) also found average seed damage of $3.54 \%, 2.68 \%$ and $1.32 \%$ for cowpea, maize and soybean, respectively, for single row multi-crop planter having plastic metering flutes.

The following research findings were drawn as per the study conducted.

The metering mechanism consisted of Anjul celled seed metering roller, seed box, seed cleaning brush and a feeding chute. The seed roller was two semi-circulars split form mounted on a metal circular flange. The seed metering mechanism was able to meter one seed per hill most of the time. The quality of the feed index was 100 percent. No missing or multiple indexes was observed. There was no damage caused to metered seeds by seed metering mechanism. As no seed damage is caused by the seed metering mechanism, hence it justifies its name-Anjul (a Hindi word 
which means a double handful). The cell size of this metering mechanism may be varied to make it suitable for other round seeds.

\section{References}

Adekanye, T.A., Akande and Mary, A. 2015. Development and Evaluation of a Manual Multi-crop Planter for Peasant Farmers. Elixir Agriculture. 86.

Balasubramanian, S., Singh, K.K., and Kumar, R. 2012. Physical properties of coriander seeds at different moisture content. Int. Agrophys. 26:419-422.

Bamgboye, I., and Mofolasayo, A.S. 2006. Performance Evaluation of a Two-Row Okra Planter. Agricultural Engineering International: the CIGR Ejournal, Vol. VIII. July.

Dineshkumar, R., and Jaimin, P. 2014. Performance Evaluation of Manually Operated Single Row Cotton Planter. International Journal of Engineering sciences \& Research Technology. 3(9): 40-44.

Gaixia, Z., Zhenhua, W., Gang, H., Guilin, L., and Li, Y. 2015. Design of Metering Device Key Parts of Pneumatic Grass Seeder. Journal of Earth Science and Engineering. 5: 289-295.

Garg, I.K., and Dixit, A. 2003. Development and evaluation of manually operated garlic planter. Agricultural Mechanization in Asia, Africa and Latin America. 34 (2): 19-22.

Jayan, P.R., and Kumar, V.J.F. 2004. Planter design in relation to the physical properties of seeds. Journal of Tropical Agriculture. 42(1-2): 69-71.

Kenghe, R., Manohar, N., Prabhakar, and Shirkole, S. 2013. Moisture Dependent Physical Properties of Soybean. Journal of Food Science and Technology. 3: 3807-3814.

Kilickan, A., Ucer, N., and Yalcin, I. 2010. Some physical properties of spinach (Spinacia oleracea L.) seed. African Journal of Biotechnology. 9(5): 648-655.
Kushwaha, H.L., Srivastava, A.P., and Singh, H. 2007. A study on physical properties of okra pod and seed. Journal of Agricultural Engineering. 44: 8891.

Mishra, J.N., Ghosal, M.K., and Das, R.K. 2015. Design modifications of Cup in Cup Feed Metering Seed Drill for Seed Pattern Characteristics Study of Green Gram Seeds. International Journal of Tropical Agriculture. 33(1): 75-80.

Murray, J.R., Tullberg, J.N., and Basnet, B.B. 2006. Planters and their components: types, attributes, functional requirements, classification and description. ACIAR Monograph No. 121.

Reddy, B.S., and Adake, R.V. 2012. Performance of Seed Planter Metering Mechanisms under Simulated Conditions. Indian J. Dryland Agric. Res. \& Dev. 27(2): 36-42.

Sahoo, P.K., and Srivastava, A.P. 2000. Development and performance evaluation of okra planter. Journal of Agricultural Engineering. 37(2):15-25.

Singh, H., Kushwaha, H.L., and Mishra, D.2007. Development of seed drill for sowing on furrow slants to increase the productivity and sustainability of arid crops. Biosystems Engineering. 98(2): 176-184.

Singh, R.C., Singh, G., and Saraswat, D.C. 2005. Optimization of design and operational parameters of a pneumatic seed metering device for planting cotton seeds. Biosyst. Eng. 92(4): 429-438.

Yadachi, S., Mani, I., Kalra, M.S., Kumar, A., and Sahoo, P.K. 2013. Development and evaluation of inclined plate metering mechanism for carrot seed. Journal of Agricultural Engineering. 50(2): 10-16.

Yalcin, I., Zarslan, C.O., and Akbas, T. 2007. Physical properties of pea (Pisum sativum) seed. Journal of Food Engineering. 79: 731735 .

\section{How to cite this article:}

Vinod Kumar, Vijaya Rani, Mukesh Jain, Anil Kumar, Sushil Kumar and Naresh. 2018. Design of 'Anjul' Seed Metering Mechanism for Round Seeds and its Seed Pattern Characteristics. Int.J.Curr.Microbiol.App.Sci. 7(03): 1536-1543. doi: https://doi.org/10.20546/ijcmas.2018.703.183 